九州大学学術情報リポジトリ

Kyushu University Institutional Repository

\title{
Degree of Abortion and Germination Rates in Triploid Seeds from Crosses between Diploid and Tetraploid Grapes (Vitis vinifera L.. and V. complex)
}

Wakana, Akira

Laboratory of Fruit Tree Science, Division of Agricultural Ecology, Department of Plant

Resources, Faculty of Agriculture, Kyushu University

Hiramatsu, Michikazu

Laboratory of Vegetable and Ornamental Crops, Division of Agricultural Ecology, Department of Plant Resources, Faculty of Agriculture, Kyushu University

Park, Sung Min

Laboratory of Fruit Tree Science, Division of Agricultural Ecology, Department of Plant

Resources, Graduate School of Bioresource and Bioenvironmental Sciences, Kyushu University

Hanada, Nobuaki

Laboratory of Fruit Tree Science, University Farm, Faculty of Agriculture, Kyushu University

他

https://doi.org/10.5109/24441

出版情報: 九州大学大学院農学研究院紀要. 46 (2)，pp. 281-294，2002-02-28. Kyushu University バージョン：

権利関係: 
J. Fac. Agr., Kyushu Univ., 46 (2), 281-294 (2002)

\title{
Degree of Abortion and Germination Rates in Triploid Seeds from Crosses between Diploid and Tetraploid Grapes (Vitis vinifera $L$. and $V$. complex)
}

\author{
Akira WAKANA ${ }^{*}$, Michikazu HIRAMATSU ${ }^{2}$, Sung Min PARK**, \\ Nobuaki HANADA***, Isao FUKUDOME*** \\ and Binh Xuan NGO**
}

\begin{abstract}
'Laboratory of Fruit Tree Science, Division of Agricultural Ecology, Department of Plant Resources, Faculty of Agriculture, Kyushu University, Fukuoka 811-2307.

${ }^{2}$ Laboratory of Vegetable and Ornamental Crops, Division of Agricultural Ecology, Department of Plant Resources, Faculty of Agriculture, Kyushu University, Fukuoka 811-2307.

(Received October 31, 2001 and accepted November 20, 2001)
\end{abstract}

\begin{abstract}
Interploid crosses were carried out using seven diploid and four tetraploid grape cultivars to examine the degree of triploid seed development. The average number of seeds per pollinated flower was 0.42 for $2 \mathrm{x} \times 4 \mathrm{x}, 0.51$ for $4 \mathrm{x} \times 2 \mathrm{x}, 0.78$ for $4 \mathrm{x} \times 4 \mathrm{x}$ and 1.21 for $2 \mathrm{x} \times 2 \mathrm{x}$ crosses. About $47 \%$ of seeds from the $2 x \times 4 x$ crosses and $44 \%$ of seeds from the $4 x \times 2 x$ crosses were sinkers. Nineteen of 1012 seeds from the $2 x \times 4 x$ crosses and 32 of 1170 seeds from the $4 x \times 2 x$ crosses germinated. Among these crosses, 'Yufu' $\times$ 'Sekirei' and its reciprocal cross exhibited the highest $(4.4 \%)$ and next highest (3.6\%) rates of seedling production per flower. All of the seedlings examined were triploid ( $2 \mathrm{n}=3 \mathrm{x}=57$ ). In comparison with diploid and tetraplid seeds from the intraploid crosses, reduction of seed size was prominent in seeds from the $4 \mathrm{x} \times 2 \mathrm{x}$ crosses but not in seeds from the $2 \mathrm{x} \times 4 \mathrm{x}$ crosses. About $10 \%$ to $30 \%$ of seeds from the interploid crosses had fully developed endosperm and $80 \%$ of seeds with the fully developed endosperm contained embryos at globular to torpedo stages. The rate of seeds with embryo was higher in the $4 \mathrm{x} \times 2 \mathrm{x}$ crosses than the $2 \mathrm{x} \times 4 \mathrm{x}$ crosses. However, difference in embryo and endosperm development was not detected between the $2 \mathrm{x} \times 4 \mathrm{x}$ and $4 \mathrm{x} \times 2 \mathrm{x}$ crosses. These results suggested that in the interploid crosses endosperm block is partial or flexible and that germination rates of the triploid seeds are very low but different in different crosses.
\end{abstract}

\section{INTRODUCTION}

Seedlessness is one of the desirable characters for breeding table grapes and raisin grapes. Seedless grapes have gained in use as table grapes in Japan as well as in the world. Winkler et al. (1962) divided setting of berries into four types, i.e., stimulative parthenocarpy, stenospermocarpy, empty seededness and normal set. Stimulative parthenocarpy is attributed to defective embryo sac formation and high germinability of pollen in cultivars such as 'Black Corinth'. However, stimulus of pollination and nutritional stimulus resulting from girdling or spraying open flowers with auxin or gibberellin (Coombe, 1950; Weaver and Williams, 1950; Weaver, 1952) were also necessary to satis-

* Corresponding author (E-mail: wakana@farm.kyushu-u.ac.jp)

** Laboratory of Fruit Tree Science, Division of Agricultural Ecology, Department of Plant Resources, Graduate School of Bioresource and Bioenvironmental Sciences, Kyushu University

*** Laboratory of Fruit Tree Science, University Farm, Faculty of Agriculture, Kyushu University, Fukuoka 811-2307 
factory set of fruits. Stenospermocarpy occurs in cultivars such as 'Thompson Seedless' in which pollination and fertilization followed by embryo abortion in the very early stage of embryogenesis are prerequisite for subsequent fruit growth. The stimulative parthenocarpy and stenospermocarpy are important genetic characters for breeding seedless grapes.

Although modern breeding of seedless grape cultivars in the world was mainly dependent upon the usage of stenosprmocarpic cultivars, triploid cultivars such as 'Kingdela' and 'Honey Seedless' and aneuploid (4x-1) cultivar 'Takao' (Ashikawa, 1972; Yamane et al., 1978) were also bred in Japan. Unbalanced chromosome numbers in these cultivars result in the formation of unfunctional pollen and embryo sac and, consequently, in the formation of seedless fruit. In these cultivars, gibberellin treatment just after anthesis is necessary to satisfactory set and growth of fruits.

As compared with the breeding of seedless grapes using stenospermocarpic cultivars, breeding of triploid seedless grapes with diploid and tetraploid cultivars is considered to be superior in the following points. (1) Since the seedlessness in triploid grapes results from their unbalance chromosome numbers, any diploid and tetraploid grapes would be expected to be used as seed and/or pollen parents. (2) Tetraploid sports are relatively easily induced from given diploid cultivars by colchicine treatment. (3) Very high male and female sterility is expected in the triploid grapes because of their relatively large chromosome number $(2 \mathrm{n}=3 \mathrm{x}=57)$, since the rates of their functional euploid ( $1 \mathrm{x}$ or $2 \mathrm{x}$ ) gametes are calculated to be only about $1.9 \times 10^{-6} \%$, and since almost all of aneuploid gametes are considered to be unfunctional (Park et al., 1999).

Seed abortion following crosses between diploid and tetraploid plants has been reported in Vitis (Einset and Lamb, 1951; Einset and Pratt, 1954; Alley, 1957; Yamashita et al.,1993 and 1995), Citrus (Esen and Soost, 1973) and the other fruit trees (see Sanford, 1983) as well as in many genera of angiosperms (eg. Brink and Cooper, 1947). For establishing triploid grapes efficiently, it is important to know the extent of seed abortion and the rates of seed germination in various reciprocal crosses between diploid and tetraploid cultivars, and to rescue underdeveloped triploid embryos in the abortive seeds.

This study was designated to demonstrate the degree of seed abortion in various reciprocal crosses between diploid and tetraploid cultivars as the basis for triploid breeding and subsequent aneuploid breeding in grape.

\section{MATERIALS AND METHODS}

\section{Plant materials}

Seven diploid cultivars and four tetraploid cultivars were chosen as seed and/or pollen parents to examine the extent of triploid seed development and to produce triploid hybrids. Of the seven diploid cultivars, five cultivars 'Muscat of Alexandoria', 'Rosario Bianco', 'Rizamat', 'Sekirei' and 'Neo Muscat' and one tetraploid cultivar 'Cannon Hall Muscat' are Vitis vinifera cultivars. However, it is uncertain whether 'Sekirei' and 'Neo Muscat' are $V$. vinifera or not, since these cultivars have 'Koshu' ( $V$. vinifera hybrid?: Ohmi et al.,1993) in their pedigrees. The remaining two diploid cultivars 'Muscat Bailey A' and 'Delaware' and three tetraploid cultivars 'Kyoho', 'Red Pearl' and 'Yufu' are intercontinental hybrid cultivars ( $V$. complex) with $V$. vinifera and North American Vitis 
species in their pedigrees. Of the four tetraploid cultivars, 'Red Pearl' and 'Yufu' were selected from natural giant sports of 'Delaware' and 'Muscat Bailey A', respectively. All these cultivars were 10- to 15-year-old trees grown in the Sasagri Orchard of the University Farm, Kyushu University, Fukuoka.

\section{Seed germination test}

Sixteen reciprocal interploid crosses and seven intraploid crosses were carried out using five diploid and three tetraploid cultivars. Additional three interploid bcrosses between 'Yufu' and three diploid cultivars were also made.

Number of flower buds per cluster was adjusted before pollination so that each cluster had about 50-100 flowers. The flower buds were emasculated one or two days before anthesis, washed with running water or sprayed with water to prevent self-pollination and bagged. Hand pollination was carried out at the full bloom stage of the clusters using fresh pollen collected from just opened flowers of the pollen parents. Pistils with wet stiguma were used for pollination, but those with dry stigma and/or abnormal morphology were removed from the clusters. Immediately after the pollination, the pollinated flower clusters were bagged again to prevent further pollination.

Berries were harvested at the fully mature stage. Seeds extracted from the berries were separated using water into two categories, floaters and sinkers. Only sinkers were set in $30 \times 40 \mathrm{~cm}$ nursery boxes filled with wet sand and stored under natural conditions. In May of the next year, the nursery boxes were carried to a green house to facilitate seed germination, and number of seeds germinating was scored in each cross. The seedlings were planted in $24 \times 30 \mathrm{~cm}$ pots filled with mold and soil (1:1) for about two to three months and were transplanted in the green house in spring of the next year.

\section{Chromosome observation}

Chromosome observation was carried out as follows. The root tips from the seedlings were pretreated with $0.08 \mathrm{M}$ hydroxyquinorine for 2 hours, fixed with alcohol propionic acid (2.5:1), hydrolyzed with $1 \mathrm{~N} \mathrm{HCl}$ at $60^{\circ} \mathrm{C}$ for 5 minutes, stained with $1 \%$ lacto propiono orcein (Dyer, 1963) for 12 hours in room temperature, squashed on microslides and observed under a microscope.

\section{Anatomy of seeds}

For anatomical study of seeds, reciprocal crosses between diploid and tetraploid cultivars and self-pollination treatments of the cultivars were carried out using two tetraploid cultivars 'Yufu' and 'Red Pearl' and two diploid cultivars 'Muscat Bailey A' and 'Delaware'. In addition, two $2 \mathrm{x} \times 4 \mathrm{x}$ crosses and four $4 \mathrm{x} \times 2 \mathrm{x}$ were also made using four diploid cultivars and four tetraploid cultivars. Crosses were carried out according to the procedure as mentioned afore. Berries were harvested at the mature stage in September. Seeds extracted from the berries were dissected with a pair of forceps and a surgical knife and the extent of endosperm development was examined under a dissecting microscope equipped with a micrometer. The extent of endosperm development was classified into three categories, i.e., (1) fully developed, (2) partially developed, and (3) almost or perfectly degenerated endosperm. Then, embryos were extracted from the dissected seeds and the morphology and length of them were examined under the dissecting microscope. 


\section{RRESULTS}

\section{Seed set}

In reciprocal interploid crosses between five diploid and three tetraploid grape cultivars, 0.42 and 0.51 seeds per flower were obtained from $2 \mathrm{x} \times 4 \mathrm{x}$ and $4 \mathrm{x} \times 2 \mathrm{x}$ crosses respectively (Table 1). In self-pollination and reciprocal crosses in the diploid cultivars, number of seeds per flower ranged from 0.80 to 1.55 with the average of 1.21 , while in self-pollination and reciprocal crosses in the tetraploid cultivars it ranged from 0.61 to 0.95 with the average of 0.78 (Table 1 ). Thus, the average rate of seed set was the highest in the $2 \mathrm{x} \times 2 \mathrm{x}$ crosses, followed by the $4 \mathrm{x} \times 4 \mathrm{x}, 4 \mathrm{x} \times 2 \mathrm{x}$ and $2 \mathrm{x} \times 4 \mathrm{x}$ crosses. Significant difference in the rate was not detected between the $4 \mathrm{x} \times 2 \mathrm{x}$ and $2 \mathrm{x} \times 4 \mathrm{x}$ crosses at $5 \%$ level.

In reciprocal interploid crosses between three diploid cultivars and tetraploid 'Kyoho', the rate of seed set per flower was high when 'Kyoho' was used as a pollen parent, whereas in three of four reciprocal crosses between four diploid cultivars and tetraploid 'Red Pearl' it was high when 'Red Pearl' was used as a pistillate parent (Table 1). In reciprocal crosses between 'Yufu' and 'Sekirei', the rate was higher in 'Yufu' $X$ 'Sekirei' than that in the reciprocal. Additional interploid crosses between 'Yufu' and three diploid vinifera cultivars showed very high rate of seed set per flower (0.72-1.35) among the interploid crosses carried out in this study (Table 2).

Table 1. Germination rates in seeds derived from reciprocal crosses between $2 x$ and $4 x$ grape cultivars.

\begin{tabular}{|c|c|c|c|c|c|c|}
\hline \multirow{2}{*}{ Cross $^{a}$} & \multirow{2}{*}{$\begin{array}{c}\text { No. of flowers } \\
\text { pollinated } \\
\left(\text { No. }^{\mathrm{b}}\right)\end{array}$} & \multicolumn{3}{|c|}{ No. of seeds obtained } & \multirow{2}{*}{$\begin{array}{c}\text { No. of seeds } \\
\text { germinating } \\
(\%)\end{array}$} & \multirow{2}{*}{$\begin{array}{c}\text { No. of } \\
3 x \text { plants } \\
\text { obtained }\end{array}$} \\
\hline & & Floaters & Sinkers & Total & & \\
\hline \multicolumn{7}{|l|}{$2 \mathrm{x} \times 4 \mathrm{x}$} \\
\hline Muscat A. $\times$ Kyoho & $351(6)$ & 182 & 66 & 24 & $86(2.4)$ & 2 \\
\hline Muscat B.A X Kyoho & $277(4)$ & 46 & 112 & 158 & $2(1.3)$ & 2 \\
\hline Neo Muscat $\times$ Kyoho & $169(3)$ & 24 & 34 & 58 & $0(0)$ & 0 \\
\hline Delaware $\times$ Red Pearl & $158(6)$ & 28 & 28 & 56 & $0(0)$ & 0 \\
\hline Muscat A. $\times$ Red Pearl & $669(8)$ & 154 & 131 & 285 & $6(2.1)$ & 1 \\
\hline Muscat B.A $\times$ Red Pearl & $549(7)$ & 91 & 84 & 175 & $5(2.9)$ & 2 \\
\hline Neo Muscat $\times$ Red Pearl & $240(3)$ & 8 & 24 & 32 & $0(0)$ & 0 \\
\hline Sekirei $\times$ Yufu & $195(3)$ & 33 & 29 & 62 & $7(11.3)$ & 7 \\
\hline Total & $2413(37)$ & 533 & 479 & 1012 & $19(1.9)$ & 14 \\
\hline \multicolumn{7}{|l|}{$4 x \times 2 x$} \\
\hline Kyoho $\times$ Muscat A. & $245(2)$ & 12 & 10 & 22 & $0(0)$ & 0 \\
\hline Kyoho XMuscat B.A & $296(2)$ & 60 & 75 & 135 & $0(0)$ & 0 \\
\hline Kyoho × Neo Muscat & $203(2)$ & 18 & 50 & 68 & $0(0)$ & 0 \\
\hline Red Pearl $\times$ Delaware & $192(5)$ & 46 & 2 & 48 & $0(0)$ & 0 \\
\hline Red Pearl $\times$ Muscat A. & $344(9)$ & 208 & 62 & 270 & $0(0)$ & 0 \\
\hline Red Pearl $\times$ Muscat B.A & $142(3)$ & 15 & 89 & 104 & $0(0)$ & 0 \\
\hline Red Pearl $\times$ Neo Muscat & $193(6)$ & 60 & 64 & 124 & $2(1.6)$ & 2 \\
\hline Yufu $\times$ Sekirei & $680(10)$ & 234 & 165 & 399 & $30(7.5)$ & 30 \\
\hline Total & $2295(39)$ & 653 & 517 & 1170 & $32(2.7)$ & 32 \\
\hline
\end{tabular}


Table 1. Continued.

\begin{tabular}{|c|c|c|c|c|c|c|}
\hline \multirow[b]{2}{*}{ Cross $^{a}$} & \multirow{2}{*}{$\begin{array}{l}\text { No. of flowers } \\
\text { pollinated } \\
\left(\text { No. }^{b}\right)\end{array}$} & \multicolumn{3}{|c|}{ No. of seeds obtained } & \multirow{2}{*}{$\begin{array}{l}\text { No. of seeds } \\
\text { germinating } \\
\text { (\%) }\end{array}$} & \multirow{2}{*}{$\begin{array}{c}\text { No. of } \\
3 \times \text { plants } \\
\text { obtained }\end{array}$} \\
\hline & & Floaters & Sinkers & Total & & \\
\hline \multicolumn{7}{|l|}{$2 x \times 2 x$} \\
\hline Delaware $\times$ Delaware & $240(4)$ & 19 & 174 & 193 & - & - \\
\hline Delawarc $\times$ Muscat $A$. & $213(4)$ & 7 & 248 & 255 & - & - \\
\hline Muscat A. $\times$ Delaware & $173(3)$ & 7 & 211 & 218 & - & - \\
\hline Muscat A. $\times$ Muscat A. & $264(4)$ & 26 & 382 & 408 & - & - \\
\hline Total & $890(15)$ & 59 & 1015 & 1074 & - & - \\
\hline \multicolumn{7}{|l|}{$4 \mathrm{x} \times 4 \mathrm{x}$} \\
\hline Red Pearl $\times$ Yufu & $241(4)$ & 24 & 124 & 148 & - & - \\
\hline Yufu $\times$ Yufu & $191(3)$ & 67 & 101 & 168 & - & - \\
\hline Yufu $\times$ Red Pearl & $112(2)$ & 53 & 53 & 106 & - & $\ldots$ \\
\hline Total & $544(9)$ & 144 & 278 & 422 & - & - \\
\hline
\end{tabular}

${ }^{a}$ Muscat. A.: Muscat of Alexandria; Muscat B. A: Muscat Bailey A. ${ }^{\circ}$ Number of clusters used.

Table 2. Germination rates in the seeds obtained from 'Yufu' crossed with $2 x$ cultivars.

\begin{tabular}{|c|c|c|c|c|c|c|}
\hline \multirow[b]{2}{*}{ Cross $^{4}$} & \multirow{2}{*}{$\begin{array}{l}\text { No. of flowers } \\
\text { pollinated } \\
\left.\text { (No. }{ }^{\circ}\right)\end{array}$} & \multicolumn{3}{|c|}{ No. of seeds obtained } & \multirow{2}{*}{$\begin{array}{c}\text { No. of seeds } \\
\text { germinating } \\
(\%)\end{array}$} & \multirow{2}{*}{$\begin{array}{l}\text { No. of } \\
3 \times \text { plants } \\
\text { obtained }\end{array}$} \\
\hline & & Floaters & Sinkers & Total & & \\
\hline Yufu $\times$ Muscat A. & $295(6)$ & 181 & 45 & 226 & $3(1.3)$ & 0 \\
\hline Yufu $\times$ Rozario Bianco & $494(4)$ & 212 & 143 & 355 & $3(0.8)$ & 2 \\
\hline Yufu $\times$ Rizamat & $206(3)$ & 206 & 73 & 279 & $1(0.4)$ & 1 \\
\hline Total & $995(13)$ & 599 & 261 & 860 & $7(0.8)$ & 3 \\
\hline
\end{tabular}

a Muscat A.: Muscat of Alexandria. "No. of clusters used.

\section{Germination of triploid seed}

In 16 reciprocal crosses between five diploid and three tetraploid grape cultivars, a total of 1012 and 1170 seeds were obtained from $2 \mathrm{x} \times 4 \mathrm{x}$ and $4 \mathrm{x} \times 2 \mathrm{x}$ crosses respectively (Table 1). About $47 \%$ of the seeds from the $2 x \times 4 x$ and $44 \%$ of the seeds from the $4 x \times$ $2 \mathrm{x}$ were sinkers reflecting the presence of endosperm and/or embryos, while more than half of the seeds were floaters in each of the interploid crosses. The floaters were empty seeds without endosperm and embryos. Although the rate of sinkers was not significantly different between the $2 x \times 4 x$ and $4 x \times 2 x$ crosses, it was significantly different between the $2 x \times 2 x$ and $4 x \times 4 x$ crosses at $5 \%$ level, i.e., it was very high (95\%) in the $2 x \times 2 x$ crosses and high $(66 \%)$ in the $4 \mathrm{x} \times 4 \mathrm{x}$ crosses as compared with the $2 \mathrm{x} \times 4 \mathrm{x}$ and $4 \mathrm{x} \times 2 \mathrm{x}$ crosses. The rates of sinkers were also low (20-40\%) in three additional interploid crosses between tetraploid 'Yufu' and diploid cultivars (Table 2).

Of the 1012 seeds derived from the $2 \mathrm{x} \times 4 \mathrm{x}$ crosses, 19 seeds germinated in five of eight cross combinations. In this case, 'Sekirei' $\times$ 'Yufu' showed the highest rate (11.3\%) 


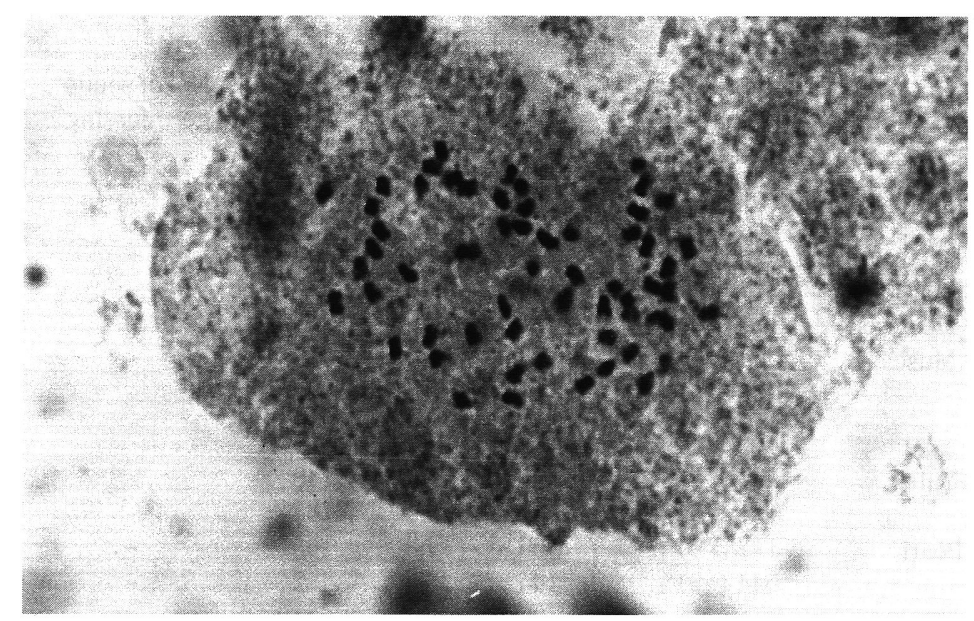

Fig. 1. Metaphase figure in the root tip cell of triploid seedling RN-8601 derived from 'Red Pearl' $\times$ 'Neo Muscat', showing 57 chromosomes.

of seed germination. In the $4 \mathrm{x} \times 2 \mathrm{x}$ crosses, 32 of the 1170 seeds germinated. The 32 seeds were derived from two of eight cross combinations, and seeds from 'Yufu' $\times$ 'Sekirei' showed the highest germination rate (7.5\%) (Table 1). In the three additional $4 x \times 2 x$ crosses with 'Yufu' as a seed parent, however, seed germination rates (0.4-1.3\%) were lower than that in 'Yufu' $\times$ 'Sekirei' (Table 2).

A total of 49 seedlings were derived from the reciprocal crosses between diploid and tetraploid cultivars and from the three additional interploid crosses (Table 1 and 2). However, five seedlings from the $2 \mathrm{x} \times 4 \mathrm{x}$ crosses died of damping-off just after germination. Thus, ploidy of the five seedlings could not be determined. Chromosome number observation in root tip cells indicated that all seedlings obtained were triploid plants with 57 chromosomes (Fig. 1). In the reciprocal crosses between diploid and tetraploid cultivars, number of triploid seedlings obtained was $5.8 \times 10^{-3}$ per flower in the $2 \mathrm{x} \times 4 \mathrm{x}$ crosses and $13.9 \times 10^{-3}$ per flower in the $4 \times \times 2 x$ crosses, while for the three additonal $4 \mathrm{x} \times 2 \mathrm{x}$ crosses it was $3.0 \times 10^{-3}$ per flower in average. These triploid seedlings were very vigorous and showed rapid growth as compared with diploid seedlings from self-pollinated diploid cultivars.

\section{Variation of seed size}

When the sizes of triploid seeds from interploid crosses were compared with those of diploid and tetraploid seeds from the self-pollinated seed parents, significant reduction of seed size was detected in two of four $2 \mathrm{x} \times 4 \mathrm{x}$ crosses and all six $4 \mathrm{x} \times 2 \mathrm{x}$ crosses, i.e., the length of triploid seeds was about $93 \%$ for two crosses of 'Delaware' with two $4 x$ cultivars, $92 \%$ for three crosses of 'Red Pearl' with three $2 x$ cultivars and $90 \%$ for three crosses of 'Yufu' with three 2x cultivars (Table 3). However, the sizes of triploid seeds from two crosses of 'Muscat Bailey A' with two 2x cultivars were almost the same as those of diploid seeds from self-pollinated 'Muscat Bailey A'. 
Table 3. Variation of seed size in $2 \mathrm{x} \times 2 \mathrm{x}, 2 \mathrm{x} \times 4 \mathrm{x}, 4 \mathrm{x} \times 2 \mathrm{x}$ and $4 \mathrm{x} \times 4 \mathrm{x}$ crosses.

\begin{tabular}{lcc}
\hline Cross & $\begin{array}{c}\text { No. of seeds } \\
\text { examined }\end{array}$ & $\begin{array}{c}\text { Seed length } \pm \mathrm{SE} \\
(\mathrm{mm})\end{array}$ \\
\hline $2 \times \times 4 \mathrm{x}$ & & \\
Delaware $\times$ Cannon Hall Muscat & 54 & $6.65 \pm 0.65$ \\
Delaware $\times$ Yufu & 165 & $6.89 \pm 0.03$ \\
Muscat Bailey A $\times$ Kyoho & 81 & $8.45 \pm 0.07$ \\
Muscat Bailey A $\times$ Red Pearl & 244 & $8.56 \pm 0.04$ \\
$4 \times \times 2 \times$ & & \\
Red Pearl $\times$ Muscat Bailey A & 138 & $6.08 \pm 0.05$ \\
Red Pearl $\times$ Rizamat & 52 & $6.18 \pm 0.06$ \\
Red Pearl $\times$ Sekirei & 70 & $6.16 \pm 0.04$ \\
Yufu $\times$ Delaware & 144 & $7.97 \pm 0.05$ \\
Yufu $\times$ Rizamat & 113 & $7.90 \pm 0.06$ \\
Yufu $\times$ Sekirei & 64 & $7.88 \pm 0.09$ \\
$2 \times \times 2 \times$ (self-pollination) & & $7.27 \pm 0.07$ \\
Delaware & 88 & $8.47 \pm 0.04$ \\
Muscat Bailey & 119 & \\
$4 \times \times 4 x$ (self-pollination) & & $6.65 \pm 0.17$ \\
Red Pearl & 85 & $8.81 \pm 0.07$ \\
Yufu & 89 & \\
\hline
\end{tabular}

\section{Extent of endosperm development}

In reciprocal interploid crosses between 'Muscat Bailey A' and 'Red Pearl' and between 'Delaware' and 'Yufu', partially developed endosperm was observed in $60-80 \%$ of seeds, while perfectly or mostly degenerated endosperm was observed in 10-30\% of seeds (Table 4). These percentages were very high as compared with those in self-pollinations of the four parental cultivars. In the four self-pollinations, about $90 \%$ of seeds had fully developed endsperm and about $90 \%$ of the seeds with fully developed endosperm had embryos, whereas in $2 x \times 4 x$ crosses about $10 \%$ of seeds had fully developed endosperm and $83 \%$ of the seeds with fully developed endosperm had embryos. In $4 \mathrm{x} \times 2 \mathrm{x}$ crosses, however, some different results from those in the $2 \mathrm{x} \times 4 \mathrm{x}$ crosses were observed, i.e., about $30 \%$ of seeds from 'Yufu' $X$ 'Delaware' had fully developed endosperm, and in 'Red Pearl' $\times$ 'Muscat Bailey A' only $30 \%$ of seeds with fully developed endosperm had embryos.

In all of the self-pollinations and reciprocal crosses except for 'Red Pearl' $\times$ 'Muscat Bailey A', the more the endosperm developed, the higher the rate of seeds with embryo was observed (Table 4). The rates of seeds with embryo were very low (about $40 \%$ ) in the $2 \mathrm{x} \times 4 \mathrm{x}$ crosses as compared with those in the $4 \mathrm{x} \times 2 \mathrm{x}$ (about $75 \%$ ). This result was mainly due to the difference in the rates of embryo formation in seeds with imperfectly or partially developed endosperm between the $2 \mathrm{x} \times 4 \mathrm{x}$ and $4 \mathrm{x} \times 2 \mathrm{x}$ crosses. Generally, the partially developed endosperm was watery in the $2 \mathrm{x} \times 4 \mathrm{x}$ crosses and brittle in the $4 \mathrm{x} \times 2 \mathrm{x}$ crosses. 
Table 4. The extent of endosperm and embryo development in triploid seeds from reciprocal crosses between $2 x$ and $4 x$ cultivars.

\begin{tabular}{|c|c|c|c|c|}
\hline \multirow[t]{2}{*}{ Cross } & \multicolumn{3}{|c|}{$\begin{array}{l}\text { Percentage of seeds with embryos in indicated } \\
\text { degree of endosperm development }\left(\mathrm{N}^{3}\right)\end{array}$} & \multirow[b]{2}{*}{ Total } \\
\hline & $\begin{array}{c}\text { Fully } \\
\text { developed }\end{array}$ & $\begin{array}{c}\text { Partially } \\
\text { developed }\end{array}$ & $\begin{array}{c}\text { Perfectly } \\
\text { or mostlly } \\
\text { degenerated }\end{array}$ & \\
\hline \multicolumn{5}{|l|}{$2 \mathrm{x} \times 4 \mathrm{x}$} \\
\hline Muscat B.A $\times$ Red Pearl & $80(26)$ & $55(145)$ & $23(73)$ & $48(244)$ \\
\hline Delaware $\times$ Yufu & $87(15)$ & $25(126)$ & $21(24)$ & $30(165)$ \\
\hline Total & $83(41)$ & $41(271)$ & $23(97)$ & $41(409)$ \\
\hline \multicolumn{5}{|l|}{$4 x \times 2 x$} \\
\hline Red Pearl $\times$ Muscat B.A & $30(10)$ & $94(108)$ & $35(20)$ & $80(138)$ \\
\hline Yufu $\quad \times$ Delaware & $80(45)$ & $70(86)$ & $39(13)$ & $70(144)$ \\
\hline Total & $71(55)$ & $84(194)$ & $36(33)$ & $75(282)$ \\
\hline \multicolumn{5}{|l|}{$2 \mathrm{x} \times 2 \mathrm{x}$ (self-pollination) } \\
\hline Muscat B.A & $90(110)$ & $33(3)$ & $0(6)$ & $84(119)$ \\
\hline Delaware & $90(71)$ & $14(7)$ & $30(10)$ & $77(88)$ \\
\hline Total & $90(181)$ & $20(10)$ & $19(16)$ & $82(207)$ \\
\hline \multicolumn{5}{|l|}{$4 \mathrm{x} \times 4 \mathrm{x}$ (self-pollination) } \\
\hline Yufu & $88(81)$ & $0(2)$ & $17(6)$ & $81(89)$ \\
\hline Red Pearl & $92(78)$ & $33(6)$ & $0(1)$ & $87(85)$ \\
\hline Total & $90(159)$ & $25(8)$ & $14(7)$ & $84(174)$ \\
\hline
\end{tabular}

${ }^{a}$ Number of seeds examined.

\section{Extent of triploid embryo development}

With regard to the variation of embryo size and morphology, no clear differences were found in reciprocal interploid crosses between 'Yufu' $(4 \mathrm{x})$ and 'Delaware' $(2 \mathrm{x})$ and between 'Red Pearl' ( $4 \mathrm{x}$ ) and 'Muscat Bailey A' (2x) (Fig. 2). Sizes of most embryos from self-pollinations of the diploid and tetraploid cultivars ranged from 1 to $2 \mathrm{~mm}$ in length, whereas in the crosses between diploid and tetraploid cultivars various sizes of embryos were observed (Fig. 2 and 3). Most of these embryos were smaller than those in the self-pollinations. However, it was noticeable that in the interploid crosses some embryos were larger than embryos in the self-pollinations, probably because of hormonal unbalance in the endosperm. No relationships were found between seed and embryo sizes not only in the self-pollinations of diploid and tetraploid cultivars but also in the $2 \mathrm{x} \times 4 \mathrm{x}$ and $4 \mathrm{x} \times 2 \mathrm{x}$ crosses (Fig. 4 ).

Most embryos derived from self-pollination had a normal hypocotyl and cotyledons, whereas in the interploid crosses most of embryos, except undifferentiated small globular-shaped embryos, showed abnormal morphology, i.e., malformation of hypocotyl and/or cotyledons, blimp-shaped embryos without distinct hypocotyl and cotyledons, and proliferation of embryos by budding (polyembryo formation). 

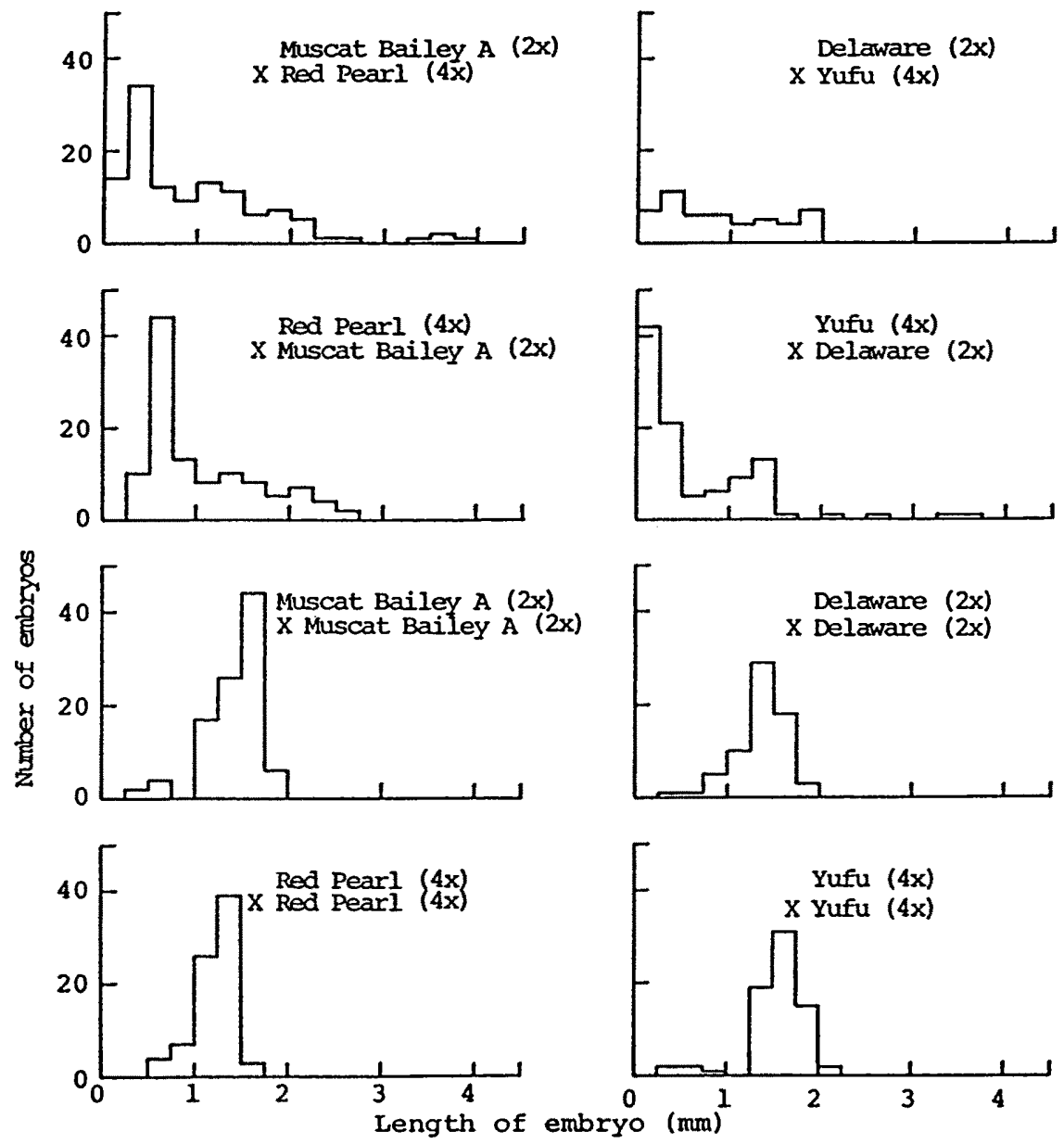

Fig. 2. Distibution frequencies of embryo with different lengths in $2 x \times 4 x, 4 x \times 2 x, 2 x \times 2 x$ and $4 \mathrm{x} \times 4 \mathrm{x}$ crosses in Vitis.

\section{DISCUSSION}

In angiosperms, embryo and endosperm are formed as the result of double fertilization. Normal fertilization within diploid species results in the formation of $2 \mathrm{x}$ embryo associated with $3 \mathrm{x}$ endosperm. Soon after fertilization, the endosperm grows rapidly and develops into a nutritive tissue for the embryo. In almost all species of angiosperms, therefore, the success of the embryo depends on the normal development of endosperm, and embryo abortion in interspecific and interploid crosses results from degeneration of endosperm during its growth (Brink and Cooper, 1947).

Sometimes seeds that are normal in size, have endosperm, are firm when pinches, 

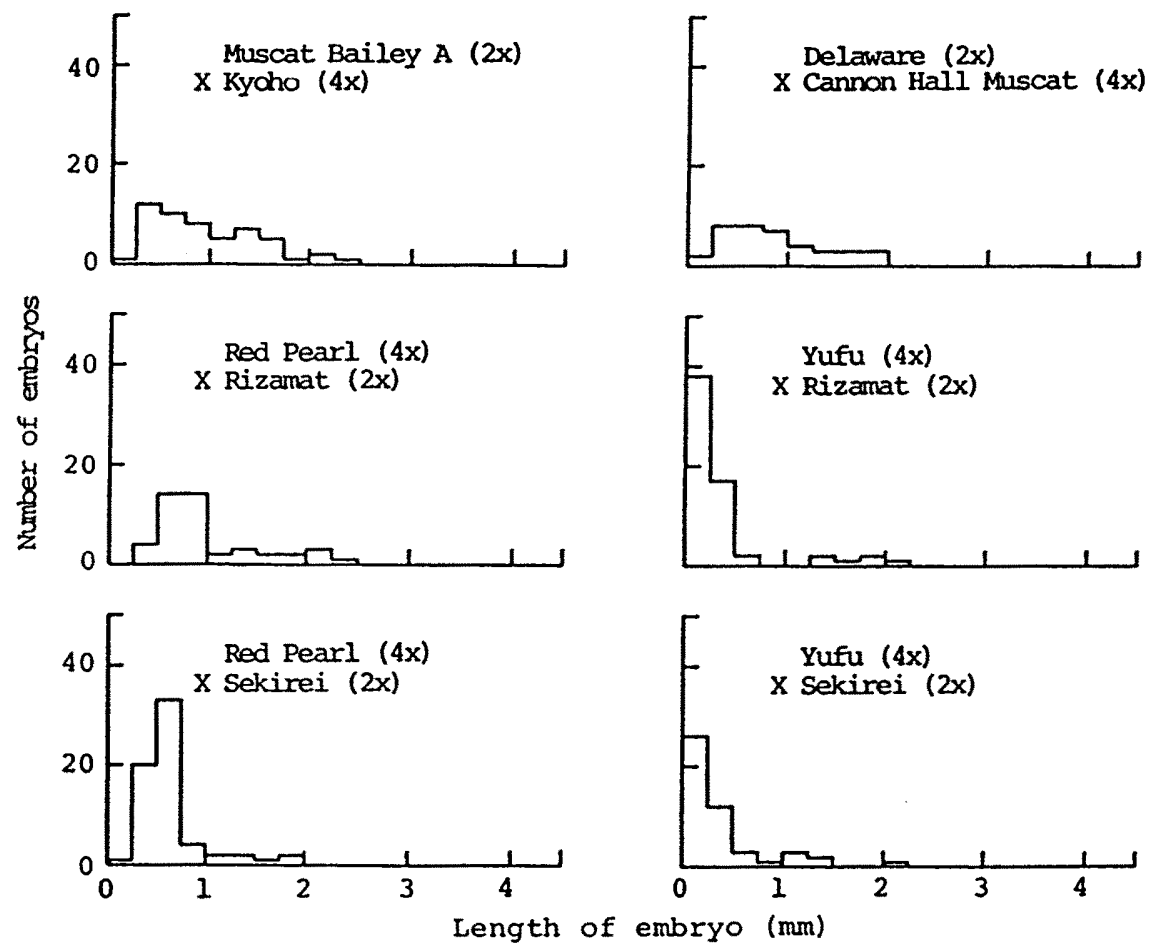

Fig. 3. Distribution frequencies of embryo with different lengths in $2 x \times 4 x$ and $4 x \times 2 x$ crosses in Vitis.

and are not infected with fungi do not have embryos. Embryoless seeds are quite common in Apiaceae, but they also occur in corn, wheat, rice, caster bean and so on (Baskin and Baskin, 2001). Automonous endosperm has been found in unfertilized ovules of Viola odorata in vitro (Wijowska et al., 1999). In the ovules, parthenogenetic development of egg cells or apogamy did not accompany automonous endosperm. We also found embryoless seeds with perfectly developed endosperm in the present interploid crosses between $2 \mathrm{x}$ and $4 \mathrm{x}$ grape cultivars and self-pollination of the parents. These results support the hypothesis of independent pathway for embryo and endosperm development.

Johnston et al. (1980) proposed the endosperm balance number (EBN) to explain the basis for normal endosperm development after interspecific and interploid crosses in Solanum. According to them, each species has an effective ploidy (EBN) in the endosperm, and it is the effective ploidies, rather than numerical ploidies, that must be in a 2:1 maternal : paternal ratio for normal endosperm development. Studies by Ehlenfeldt and Hanneman (1988) and Johnston and Hanneman (1996 and 1999) demonstrated that a few genes and more than one chromosomes were involved in determining EBN.

According to this EBN theory, all Vitis species and Vitis complexes $(2 \mathrm{n}=2 \mathrm{x}=38)$, 

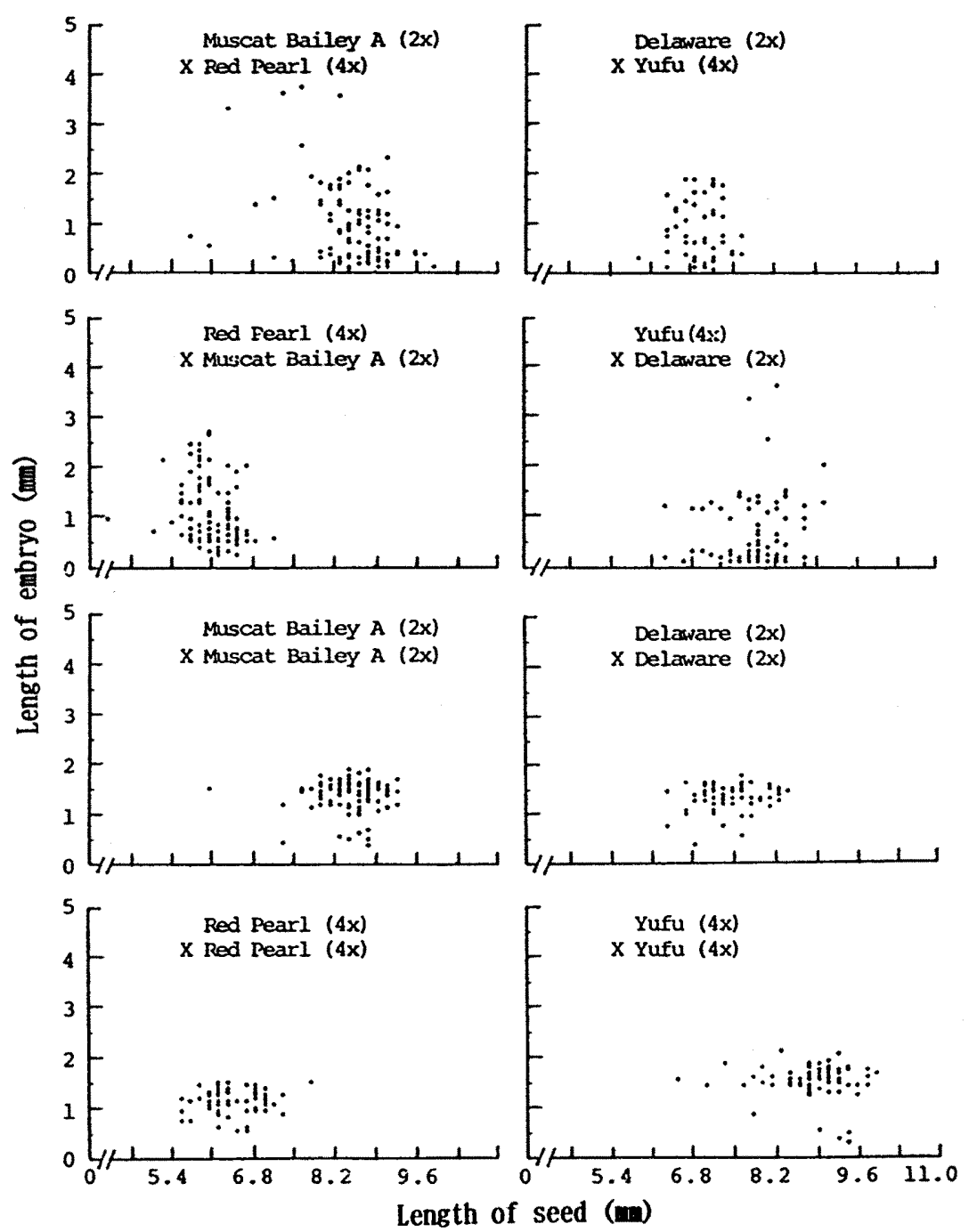

Fig. 4. Relationships between embryo and seed length in $2 x \times 4 x, 4 x \times 2 x, 2 x \times 2 x$ and $4 x \times 4 x$ crosses in Vitis. Correlation coefficient ( $\mathrm{r}$ ) is -0.358 for 'Muscat Bailey A' $\times$ 'Red Pearl', -0.275 for 'Red Pearl' $\times$ 'Muscat Bailey A', 0.055 for 'Muscat Bailey A' $\times$ 'Muscat Bailey A', 0.093 for 'Red Pearl' $\times$ 'Red Pearl', -0.34 for 'Delaware' $X$ 'Yufu', 0.121 for 'Yufu' $X$ 'Delaware', 0.140 for 'Delaware' $\times$ 'Delaware', and -0.092 for 'Yufu' $\times$ 'Yufu'. There were no significance at $5 \%$ level.

except Vitis rotundiforia $(2 \mathrm{n}=2 \mathrm{x}=40)$, are $2 \mathrm{EBN}$ and all tetraploid grapes are $4 \mathrm{EBN}$, since in Vitis there are no interspecific crossing barriers within the same ploidy (Einset and Pratt, 1975). In $2 x \times 4 x$ crosses, therefore, the resultant tetraploid endosperm with a 2:2 paternal : maternal ratio results in abortion, and in $4 \mathrm{x} \times 2 \mathrm{x}$ crosses the resultant pen- 
taploid endosperm with a 4:1 paternal : maternal ratio also results in abortion. However, this EBN theory is unable to explain the reason why the degree of endosperm breakdown after interploid crosses is different in different species and why it is different in different seeds from the same cross.

Sanford (1983) described that in fruit crops interploid endosperm block can vary from being nearly absolute (eg. Vassinium), to being flexible or partial (eg. Citrus), to being entirely absent (eg. Malus $\times$ domestica) - all depending upon the genus. The present study shows that in Vitis the interploid endosperm block is flexible or partial, since the number of seeds derived from interploid crosses between $2 \mathrm{x}$ and $4 \mathrm{x}$ cultivars was about one-half of that from self-pollinations of the $2 \mathrm{x}$ and $4 \mathrm{x}$ cultivars (Table 1), and since more than $40 \%$ of seeds from the interploid crosses were sinkers (Table 1) in which more than $80 \%$ of the seeds showed various degree of endosperm development from partial to full (Table 4). Furthermore, the facts that $2.5 \%$ of seeds from $2 \mathrm{x} \times 4 \mathrm{x}$ crosses and $1.1 \%$ of seeds from the reciprocals germinated also suggest that in grape the interploid endosperm block is flexible or partial. The reason for this flexible or partial interploid endosperm block is obscure. However, it seems that allopolyploid origin (Olmo, $1976)$ and large chromosome number $(n=19)$ in Vitis may have some role on the flexibility of endosperm block, since apple (Malus $\times$ domestica) exhibiting highly absence of endosperm block is also considered to originate from allopolyploid plants (intergeneric hybrid) with relatively large chromosome number $(n=17)$.

Yamashita et al. (1993) reported that triploid seedlings are more efficiently derived from $4 \mathrm{x} \times 2 \mathrm{x}$ than $2 \mathrm{x} \times 4 \mathrm{x}$ crosses. The present study suggests that there is no clear difference between $2 \mathrm{x} \times 4 \mathrm{x}$ and its reciprocal crosses as to the formation of perfect $3 \mathrm{x}$ seeds with germination ability. In these cross combinations, the number of perfect seeds per flower was different in different cross combinations, and 'Yufu' $\times$ 'Sekirei' and its reciprocal cross showed the highest ( 30 seeds per 680 pollinations) and the next highest ( 7 seeds per 195 pollinations) production of perfect $3 x$ seeds respectively. Interploid cross combinations exhibiting such high rates of perfect $3 x$ seed fomation as these are enough to produce triploid seedlings efficiently. However, almost all interploid crosses exhibited less than $1 \%$ of perfect seed formation per flower. In such cases, immature embryo culture and in ovulo embryo culture developed in crosses with stenospermocarpic grapes (Cain et al., 1983; Emershad and Ramming, 1984; Spiegel-Roy et al.,1985; Gray et al., 1990) and interspecific crosses between $V$. vinifera and $V$. rotundifolia (Goldy et al., 1988) may help us to produce triploid seedlings from these crosses. Recently, Yamashita et al. (1998) successfully produced triploid hybrids through in ovulo embryo culture in five interploid crosses with diploid and tetraploid cultivars.

Yamashita et al. (1993) examined the size of triploid seeds from two $2 \mathrm{x} \times 4 \mathrm{x}$ crosses ('Muscat of Alexandoria' $\times$ 'Kyoho' and 'July Muscat' $\times$ 'Kyoho') and one $4 \mathrm{x} \times 2 \mathrm{x}$ cross ('Kyoho' $\times$ 'Muscat of Alxandoria'). They found that triploid seeds from the $2 \mathrm{x} \times 4 \mathrm{x}$ crosses are larger than seeds from the open-pollinated $2 \mathrm{x}$ seed parents and that triploid seeds from the $4 \mathrm{x} \times 2 \mathrm{x}$ cross are smaller than seeds from the open-pollinated $4 \mathrm{x}$ seed parent. In six $4 \mathrm{x} \times 2 \mathrm{x}$ crosses carried out in this study with 'Yufu' and 'Red Pearl' as seed parents, significant reduction of seed size was recognized in all of the six crosses. However, our results also showed that the sizes of triploid seeds from $2 \mathrm{x} \times 4 \mathrm{x}$ crosses were almost same as those of diploid seeds from self-pollination of diploid seed parent 
'Muscat Bailey A', and were smaller than those of diploid seeds from self-pollination of seed parent 'Delaware'. These results suggest that the reduction of $3 \mathrm{x}$ seed size is common in the $4 \mathrm{x} \times 2 \mathrm{x}$ crosses but not in the $2 \mathrm{x} \times 4 \mathrm{x}$ crosses. Recently, Park et al. (2002) have found the occurrence of $4 \mathrm{x}$ seedlings from $4 \mathrm{x} \times 2 \mathrm{x}$ crosses in Vitis. Selection of the large-sized seeds in $4 \mathrm{x} \times 2 \mathrm{x}$ crosses may be a useful method to produce highly heterozygous tetraploid hybrids without using colchicine-induced tetraploid plants as pollen parents.

In summary, the triploid hybrid seedlings derived from the interploid crosses between diploid and tetraploid grape cultivars showed higher vigor than diploid seedlings from their parents. Thus, the triploid hybrids are expected to exhibit high productivity and seedlessness. To produce such triploid hybrids more efficiently from various interploid crosses, more works such as immature embryo culture (Yamashita et al, 1993 and 1995) and in ovulo culture will be required. However, the present results at hand indicate that some of interploid crosses between diploid and tetraploid cultivars produce relatively many triploid seeds with germination capability under natural conditions. Selection of such cross parents may also help us to produce triploid hybrids efficiently.

\section{REFERENCES}

Ashikawa, K. 1972 On the new grape cultivar 'Takao'. Jap. J. Breed., 22: 46-51 (in Japanese)

Baskin, C. C. and J. M. Baskin 2001 Seed. Academic Press, California

Brink, R. A. and D. C. Cooper 1947 The endosperm in seed development. Bot. Rev., 13: 423-541

Cain, D. W., R. L. Emershad and R. E. Tarailo 1983 In ovulo embryo culture and seedling development of seeded and seedless grapes (Vitis vinifera L.). Vitis, 22: 9-14

Coombe, B. G. 1950 Artificial parthenocarpy in grape vines. Jour. Austral. Inst. Agr. Sci., 16: 69-70

Dyer, A. F. 1963 The use of lacto-propiono orcein in rapid squash methods for chromosome preparations. Stain Technol., 38: 85-90

Esen, A. and R. K. Soost. 1973 Seed development in Citrus with special reference to $2 \mathrm{x} \times 4 \mathrm{x}$ crosses. Amer. J. Bot., 60: 448-462

Ehlenfeldt, M. K. and R. E. Hanneman Jr. 1988 Genetic control of endosperm balance number (EBN): three additive loci in a threshold like system. Theor. Appl. Genet., 75: 825-832

Einset, J. and B. Lamb 1951 Chimeral sports of grapes. J. Hered., 42: 158-162.

Einset, J. and C. Pratt 1954 "Giant" sports of grapes. Proc. Amer. Soc. Hort. Sci., 63: 251-256

Einset, J. and C. Pratt 1975 Grape. In: Janick, J. and N. Moore (eds), Advances in fruit breeding. Purdue Univ. Press, West Lafayette p. 130-153

Emershad, R. L. and D. W. Ramming 1984 In ovulo embryo culture of Vitis vinifera L. cv. Thompson Seedless. Amer. J. Bot., 71:873-877

Goldy, R., R. L. Emershad, D. W. Ramming and J. Chaparo 1988 Embryo culture as a means of introgressing seedlessness from Vitis vinifera to Vitis rotundifolia. Hort. Sci, 23: 886-869

Gray, D. J., J. A. Mortensen, C. M. Benton, R. E. Durham and G. A. Moore 1990 Ovule culture to obtain progeny from hybrid seedless bunch grapes. J. Amer. Soc. Hort. Sci., 115: 1019-1024

Johnston, S. A., and R. E. Hanneman Jr. 1996 Genetic control of endosperm balance Number (EBN) in the Solanaceae based on trisomic and mutation analysis. Genome, 39: 314-321

Johnston, S. A., and R. E. Hanneman Jr. 1999 The nature of the genetic control of endosperm balance number based on aneuploid analysis of Datura. Sex. Plant Reprod., 12: $71-75$

Johnston, S. A., T. P. M. den Nijs, S. J. Peloquin and R. E. Hanneman Jr. 1980 The significance of genic balance to endosperm development in interspecific crosses. Theor. Appl. Genet., 57:5-9

Ohmi, C., A. Wakana and S. Shiraishi 1993 Study of the parentage of grape cultivars by genetic interpretation of GPI-2 and PGM-2 isozymes. Euphytica, 65: 195-202

Olmo, H. P. 1976 Grape. In Simmonds, N. W. (ed.), Evolution of crop plants. Longman, London. p. $294-298$ 
Park, S. M., M. Hiramatsu and A. Wakana 1999 Aneuploid plants derived from crosses with triploid grapes through immature seed culture and subsequent embryo culture. Plant Cell, Tissue and Organ Culture, 59: 125-133

Park, S. M., A. Wakana, M. Hiramatsu and K. Ureshino 2002 A tetraploid hybrid plant from $4 \mathrm{x} \times 2 \mathrm{x}$ crosses in Vitis and its origin. Euphytica, (in press)

Sanford, J. C. 1983 Ploidy manipulations. In Moore, N. and J. Janick (eds) Methods in fruit breeding. Purdue Univ. Press, West Lafayette, p. 100-123

Spiegel-Roy, P., I. Baron and U. Lavi 1985 In vitro culture and plant formation from grape cultivars with abortive ovules and seeds. J. Amer. Soc. Hort. Sci., 110: 109-112

Weaver, R. J. and W. O. Wiliams. 1950 Response of flowers of Black Corinth and fruit of Thompson Seedless grapes to applications of plant growth-regulators. Bot. Gaz., 111: 477-485

Weaver, R. J. 1952 Thinning and girdling of Red Malaga grapes in relation to size of berry, color, and percentage of total soluble solids of fruit. Proc. Amer. Soc. Hort. Sci., 60: 132-150

Wijowska, M., E. Kuta and L. Przywara 1999 Automonous endosperm induction by in vitro culture of unfertilized ovules of Viola odorata L. Sex. Plant Reprod., 12: 164-170

Winkler, A. J., J. A. Cook., W. M. Kliewer and L. A. Lider 1962 General viticulture. California Univ. Press, Berkley

Yamane, H., A. Kurihara and R. Tanaka 1978 Studies on polyploidy breeding in grapes. 1. Chromosome numbers of large-berried grape varieties grown in Japan. Bull.Fruit Tree Res. Stn., E2: 1-8 (in Japanese with English summary)

Yamashita, H., S. Horiuchi and T. Taira 1993 Development of seeds and the growth of triploid seedlings obtained from reciprocal crosses between diploids and tetraploids grapes. J. Jap. Soc. Hort. Sci., 63: 249-255 (in Japanese with English summary)

Yamashita, H., T. Haniuda and H. Shiba 1995 In vitro culture of embryos obtained by crossing tetraploid cultivar Kyoho with diploid cultivars. J. Jap. Soc. Hort. Sci., 65: 719-724 (in Japanese with English summary)

Yamashita, H., I. Shigehara and H. Haniuda 1988 Production of triploid grapes by in ovulo embryo culture. Vitis, 37: 113-117 